\title{
Acute ECG ST-segment elevation as infero-lateral myocardial infarction in a patient with pulmonary embolism
}

\author{
Pinar Dogan, Murat Gul, Sinan Inci \\ Aksaray University, Aksaray Training and Research Hospital, Department of Cardiology, Aksaray, Turkey
}

ARTICLE INFO

Article history:

Submitted: 18. 5. 2019

Accepted: 15. 7. 2019

Available online: 7. 7. 2020

Klíčová slova:

12svodový EKG

Infarkt myokardu

Plicní embolie
SOUHRN

Plicní embolie a infarkt myokardu s elevacemi úseku ST jsou častou přícinou akutního postižení kardiovaskulárního systému, které může rychle vést ke zhoršení hemodynamiky pacienta. Sedmdesátiletá žena byla přivezena na oddělení akutního příjmu se srdeční zástavou. EKG vyšetření prokázalo sinusový rytmus s blokádou pravého Tawarova raménka s elevacemi úseku ST v inferolaterálních svodech. Podle koronarogramu byla př́činou neobstrukční ischemická choroba srdeční s několika pláty. CT angiografie plic prokázala subtotální uzávěr levé plicní tepny a četné defekty plnění v obou distálních segmentech plic. Tato kazuistika upozorňuje na nutnost podezření na akutní plicní embolii u každého pacienta s infarktem myokardu s elevacemi úseku ST a nepostiženými koronárními tepnami.

(c) 2020, ČKS.
Keywords:

12-lead ECG

Myocardial infarction

Pulmonary embolism

\begin{abstract}
Pulmonary embolism and ST-elevation myocardial infarction are both common causes of cardiovascular emergency which may rapidly lead to hemodynamic deterioration. A 70-year-old female brought to emergency department in cardiac arrest. The electrocardiogram (ECG) revealed sinus rhythm with right bundle branch block, ST-elevations in inferolateral leads. Her coronary angiogram showed non-obstructive coronary artery disease with a few plaques. A CT pulmonary angiogram showed subtotal occlusion of left main pulmonary artery and multiple filling defects on bilateral pulmonary distal segments. This report emphasizes that acute PE should be suspected in every patient with ST-elevation myocardial infarction and normal coronary arteries.
\end{abstract}

\section{Introduction}

Pulmonary embolism (PE) and ST-elevation myocardial infarction (STEMI) are both common causes of cardiovascular emergency which may rapidly lead to hemodynamic deterioration. The clinical presentations of PE may be nonspecific, including dyspnea, chest pain, and tachycardia which are similar to acute coronary syndrome. Several electrocardiographic (ECG) patterns were described for PE. They range from sinus tachycardia, rightward axis deviation, complete or uncomplete right bundle branch block and S1Q3T3 sign to ST-elevation in right precordial leads." A few case reports describe ECG presentation of pulmonary embolism as ST-segment elevation in precor- dial leads, but exact mechanism is still unclear. This report describes a case of pulmonary embolism with ECG findings mimicking inferolateral myocardial infarction.

\section{Case report}

A 70-year-old female brought to emergency department in cardiac arrest. Her past medical history included poorly controlled hypertension and hyperlipidemia. The patient has complained about chest pain and sweating prior to syncope. Emergency services found her in pulseless electrical activity and initiated successful cardiopulmonary resuscitation and the patient was subsequently intubated. Upon arrival to the emergency room, blood pressure was

Address: Sinan Inci, Aksaray University, Department of Cardiology, Aksaray Training and Research Hospital, Aksaray, 06100 Ankara, Turkey, e-mail: doktorsinaninci@gmail.com DOI: 10.33678/cor.2019.056 


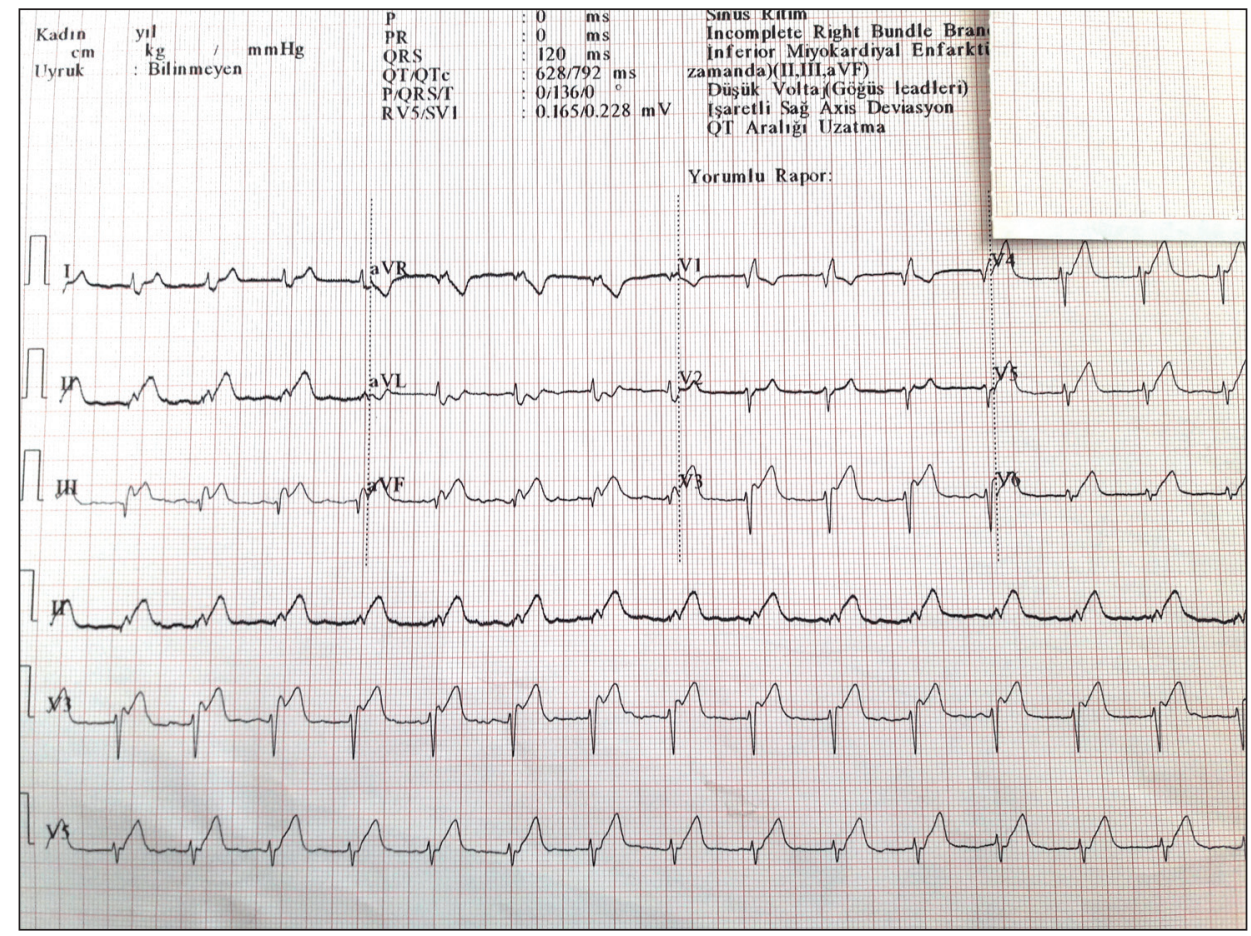

Fig. 1 - Initial ECG revealed ST-elevations in leads II, III, aVF, $\mathrm{V}_{3}-\mathrm{V}_{6}$ and ST-depression in lead aVL.
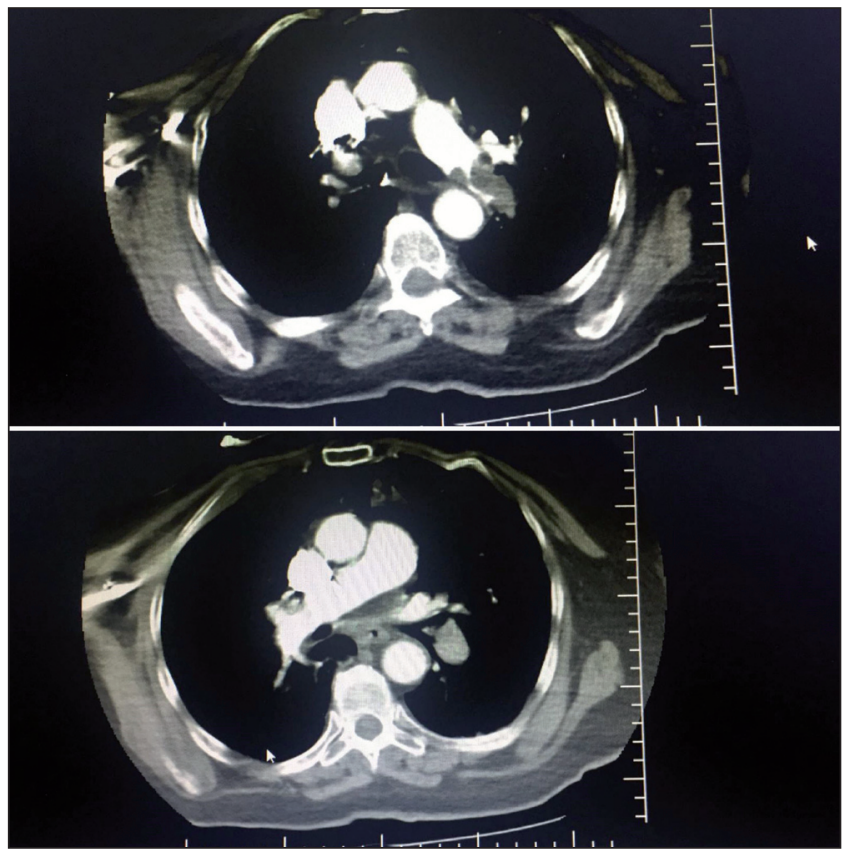

Fig. 2 - CT pulmonary angiography showed subtotal occlusion of left main pulmonary artery.

$70 / 40 \mathrm{mmHg}$, pulse rate was 95 beats/minute rhythmic, and oxygen saturation was $84 \%$ on $100 \%$ oxygenation via endotracheal tube. The initial ECG revealed sinus rhythm with right bundle branch block, ST-elevations leads II, III, aVF, $V_{3}-V_{6}$ and ST-depression in lead aVL (Fig. 1). Based on her clinical presentation and ECG findings, the patient was taken for an emergent cardiac catheterization. A second ECG taken before cardiac catheterization showed that bradycardia and progressive ST-elevation in same leads. She was hemodynamically supported by norepinephrine and an intra-aortic balloon pump. Her coronary angiogram showed non-obstructive epicardial coronary arteries. Bedside echocardiography was performed which showed a severely dilated right ventricle and no evidence of left ventricular wall motion abnormality. These findings raised a suspicion of massive pulmonary embolism. Afterwards, an emergent computed tomography pulmonary angiography was arranged and showed multiple filling defects over the left main pulmonary artery and bilateral pulmonary distal segments (Fig. 2). Following diagnosis of pulmonary thromboembolism, alteplase infusion was initiated and patient fully anticoagulated with unfractionated heparin. Unfortunately, the patient died 18 hours after admission because of profound shock.

\section{Discussion}

In the present case, the clinical presentations and ECG changes were quite mimicking inferolateral ST-segment elevation myocardial infarction (STEMI), but the final diagnosis was bilateral massive pulmonary embolism.

Pulmonary embolism is a potentially life-threatening condition that is sometimes difficult to diagnose due to nonspecific symptoms and findings. More than $90 \%$ of cases present shortness of breath and chest pain. ${ }^{2}$ Chest pain is usually pleuritic which is due to pulmonary infarction. ${ }^{3}$ Chest pain is also related with myocardial ischemia due to the increased right ventricular afterload and a disproportion between oxygen demand and supply. ${ }^{4}$ Atypical clinical and electrocardiographic findings can be challenging for diagnostics.

The ECG associated with PE is variable including ST-segment abnormalities, $T$ wave changes, a left or 
right axis deviation, a S1Q3T3 pattern, and right bundle branch block. ST-elevation is an uncommon ECG manifestation in $\mathrm{PE}$, occurring in a range of $10-30 \%$ of patients, although its incidence varies according to the ECG leads taken into account and with the degree of hemodynamic compensation. ${ }^{5}$

Although the pathophysiology of ST elevation in PE is still unclear, a few mechanisms can be proposed for explanation. The sudden elevation of right ventricular pressure and consequently increased right ventricular afterload produced by pulmonary artery outflow obstruction result in right ventricular failure and dilatation inducing myocardial ischemia. These ST elevations could also be explained by a sudden increase in pressure on the right ventricle resulting in stretching of the myocardial cells leading to ischemia, and acute coronary vasospasm, resulting in ST elevation. The severe hypoxemia that accompanies massive PE induces a catecholamine surge and further increases myocardial workload, worsening the ischemia. ${ }^{6}$

In conclusion, ST-elevation is an atypical ECG finding of PE. A bedside echocardiography is a valuable diagnostic tool in making differential diagnosis from ACS and to a fast detection of acute RV overload. The possibility of PE should be kept in the mind in a patient with ST-eleva- tion myocardial infarction when cardiac catheterization fails to identify a culprit lesion.

\section{Conflict of interest}

The authors report no financial relationships or conflicts of interest regarding the content herein.

\section{References}

1. Mohsen A, El-Kersh K. Variable ECG findings associated with pulmonary embolism. BMJ Case Rep 2013;2013:bcr2013008697.

2. Torbicki A, Perrier A, Konstantinides S, et al. Guidelines on the diagnosis and management of acute pulmonary embolism: the Task Force for the Diagnosis and Management of Acute Pulmonary Embolism of the European Society of Cardiology (ESC). Eur Heart J 2008;29:2276-2315.

3. Soloff LA, Rodman T. Acute pulmonary embolism. Am Heart J 1967;74:629-647.

4. Lin JF, Li YC, Yang PL. A case of massive pulmonary embolism with ST elevation in leads V1-4. Circ J 2009;73:1157-1159.

5. Kukla P, WF Mclntyre, Fijorek K, et al. Electrocardiographic abnormalities in patients with acute pulmonary embolism complicated by cardiogenic shock. Emerg Med 2014;32:507510.

6. Ghatak A, Alsulaimi A, Acosta YM, et al. Acute pulmonary embolism masquerading as acute myocardial infarction. Proc (Bayl Univ Med Cent) 2015;28:69-70. 